\title{
The "Small Judiciary" Policy in Japan
}

\author{
By Akira Ishikawa
}

\section{Introduction}

\section{1 "Small Judiciary" and "Big Judiciary"}

In recent times, Japanese legal professionals both from the public and private sectors have been discussing the reform of the Japanese judicial system. This discussion has centred on two opposing concepts, "Small Judiciary" (Chiisana Shiho) and "Big Judiciary" (Ohkina Shiho). Critics of the current status of the Japanese judicial system argue that the Japanese judiciary should be transformed from a "Small Judiciary" into a "Big Judiciary".

The "Small Judiciary" policy which has been traditionally adopted by the Japanese government has brought a malfunctioning of the Japanese judicial system due to a lack of human and material resources of the courts. The malfunctioning of the judicial system has in turn caused a malfunctioning of the Japanese litigation system. The lack of human and material resources has produced delays in court proceedings, thereby making litigation relatively inaccessible to the public. Further, as the number of lawyers in Japan is small compared to that of other countries and the legal aid system is poorly equipped, public access to justice is made even more difficult. In short, the judicial system is currently alienating the public.

\subsection{Comments on "Small Judiciary"}

The "Small Judiciary" being the current arrangement in Japan, the judicial system is not performing its proper function in society. Low numbers of legal professionals, inadequate human and material resources of the courts and an inaccessible court system are the result of the "Small Judiciary" dispensation. Neither the government nor the legal profession have made an effort to improve this. ${ }^{1}$ To reform the current system, it is necessary to increase both the number of lawyers and the material resources available to the judiciary, effect fundamental changes to the legal aid system and reform the civil procedure. In this regard, in November 1994, the Council for reform on Issues in Relation to Training of Legal Pro- 
fessionals (the Reform Council) issued an opinion paper. ${ }^{2}$ In addition the New Civil Procedure Code was enacted in order to simplify civil proceedings and to make them more accessible. ${ }^{3}$ However, it is submitted that the New Civil Procedure Code is only a temporary relief to alleviate public alienation. To solve the problem once and for all, the judiciary must be fundamentally reformed and changed from a "Small Judiciary" system to a "Big Judiciary" system.

Litigation is an effective way preventing or rectifying illegal acts against members of the public or against societal interests by the state, a local authority, a statutory corporation or a large private corporation. It is also an effective means of preventing or rectifying the invasion of the rights of the people by these entities. It is thus a serious shortcoming that the Japanese judiciary has not been functioning properly.

The Japan Association of Corporate Executives (Keizai Dohyukai) has pointed out that the courts have not achieved their desired function and therefore only have limited relevance. ${ }^{4}$

The Governmental Committee on Administrative Reform has also pointed out that the courts have neither been issuing a large enough amount of precedents or reliable precedents which respond to social changes. ${ }^{5}$ Hiroya Noguchi of this committee remarked further that court proceedings are not providing an effective remedy even when a defendant obtains a judgement in his favour as the defendant and his family have to devote an enormous amount of time and effort to the litigation, often for a period exceeding ten years due to delays in the proceedings. ${ }^{6}$ These statements appear to represent much of the public's unfavourable opinion on the current state of the judicial system. ${ }^{7}$

En economist at Keio University, Mr. Haruo Shimada, pointed out that the roles of the legislature and judiciary are minimised and subordinated to the overwhelming supremacy of the administration. In Japan management of the state and distribution of its resources are left to the sole discretion of administration. This means that the control of the judiciary over politics or administration in relation to the management of the state or distribution of resources is not functioning properly. ${ }^{8}$ Although I do not entirely support this view, the

2

3 1998.

4 See "Problems and Remedy of Japanese Modem Society", June 1994.

5

6 
Supreme Court has repeatedly followed the decision of the administration and hardly recognises illegal actions of the administration against the people. It has been pointed out that the Supreme Court rarely decides in favour of a victim of harm inflicted by a large corporations in a suit for compensation. ${ }^{9}$ In order to make courts and litigation more accessible a radical increase in the numbers of the practicing legal profession would seem to be called for. ${ }^{10}$

\subsection{Contents of "Small Judiciary"}

The present number of legal professions in Japan is extremely small compared with other countries. In this regard, the opinion paper for the Council for Reform of the Legal Training System states the following ${ }^{11}$ :

\section{The number of Lawyers in Japan}

The Japanese legal prof ession comprises 15,540 lawyers (as at 4 April 1995), 2,058 judges (excluding summary courts), 1,173 prosecutors (excluding deputy prosecutors) making for a total of 18,771 . Its proportion to the Japanese population (estimated to be $125,034,000$ as at 1 October 1994) is 6,600 to one legal professional. To be admitted to the legal profession in Japan (i.e. judges, prosecutors and practising lawyers), one must pass the bar examinations. The annual number of successful examinees sitting for admission to the bar examinations from 1962 to 1990 was approximately 500, 600 per annum in 1991 and 1992, and 700 per annum after 1993. The corresponding figures for other countries are 50,000 in the United States (in 1991), 3,700 in the United Kingdom (1990), 7,800 in Germany (1993), 1,500 in France (1990). Even France has twice as many people admitted to the legal profession as Japan. Factoring in Japan's population, France has 4.5 times the number of new

Also see A. Ishikawa, "Civil Proceedings Reform and Improvement of other 'Systems'", Vol. 881, Hanrei Times, p. 4, where it is stated, "however, implementation of expeditious proceedings not only depends on reform of civil proceedings but also on improvement of human and material resources of the courts. Without any of these two aspects, expeditious proceedings cannot be achieved. Compared with European countries and the United States, it has always been argued that the number of judges in Japan must be increased. The usual response to this is that quantity is not the only issue to be solved in order to improve the number of expeditious proceedings. However, the number of judges is the most significant measure to solve problems of delays in proceedings. It must be noted that the argument that the number of judges is not the only thing that needs to be changed in order to solve delays in proceedings tends to divert attention from this most important issue."

11 Freedom and Justice, December (1995), p. 167. All figures in this section are for 1995. 
Japanese legal professionals and represents the equivalent of 3,200 new legal professionals in Japan.

The ratio between judges, prosecutors and lawyers in Japan is $1: 0.57: 7.6,1: 0,84: 27$ in the United States, and 1:0,74:22 in the United Kingdom. Other countries have a higher ratio of judges and prosecutors to lawyers than Japan. On the other hand, the ratio in Germany is $1: 0.18: 3.4$ as the proportion of judges is very high. In France the ratio is $1: 0.3: 6$. The proportions of the different branches of the legal profession vary from nation to nation.

Compared with Japan, the population of legal professions is 867,000 in the United States of America (30,000 judges, 25,000 prosecutors and 812,000 lawyers), 76,200 in the United Kingdom (3,200 judges, 2,300 prosecutors and 70,700 lawyers), 81,200 in Germany (17,900 judges, 3,900 prosecutors and 59,400 lawyers), and 34,000 in France (4,600 judges, 1,400 prosecutors and 28,00 lawyers). The proportion of the population to one legal professional is thus $300: 1$ in the United States, $650: 1$ in the United Kingdom, $990: 1$ in Germany, 1,730:1 in France, compared to Japan's 6,600:1. The population per legal professional in Japan is 3.8 times higher than in France. (All figures approximate.)

\section{Current Status of the Bar Examination}

The bar examination is administered by the Japanese government for the purpose of determining whether the applicant for the legal profession (i.e. judges, prosecutors and lawyers) has the requisite legal knowledge and ability to apply that knowledge. The bar examination is the method of maintaining a legal profession which can answer to the expectations of the public. The annual number of applicants for the bar examination is approximately 20,000 . The 700 successful per annum equal a passing rate of $3 \%$. The average age of the successful examinee is approximately 28 years, and applicants sit an average number of six times for the bar exams until they pass. First-time examinees in the bar examination number approximately 4,000 per annum which is approximately $10 \%$ of total graduates from the faculties of law at universities. Of the 700 successful applicants in 1996, only 183 succeeded within 3 years of preparatory study, 387 required 5 years. In 1994, the number of successful applicants below age 24 was 229 , and below age 26, 373. Therefore a bar exam applicant has to devote a considerable amount of time in preparation for the examination. This preparation is not conducted through formal education at a university, but in specialised private schools.

As it takes a considerably long time to prepare and pass the bar examinations many law graduates choose not to prepare for the bar examinations or give up after an initial attempt. 
A survey by a judge reveals that the metropolitan (including adjacent areas) and branch areas' district court civil judges and high court judges are the busiest. In the case of the civil division of the district court, one judge deals concurrently with 200 to 300 cases, sometimes over 300. Most judges spend week day nights reading records in order to write their judgements. More than half of the judges work on Saturdays and Sundays. ${ }^{12}$ Further, the proportion of the budget only for the courts to the entire national budget reached its peak in $1964(0.93 \%)$ and has declined continually to approximately $0.4 \%$. The Supreme Court's budget request for the 1997 fiscal year is JPY 310,853 billion (an increase of $1.8 \%$ from the previous year). As the overall budget increased by $3.4 \%$, the proportion of the budget attributable to the Supreme Court has not increased accordingly. ${ }^{13}$ The number of judges in 1972 was 1,900 and the number of incoming new cases was 96,065. In 1994, these figures increased to 2,046 and 154,537 respectively. This means the number of new cases increased by $64 \%$ whilst the number of judges increased only by $7.6 \%$. The number of prosecutors remained unchanged during this period.

\section{Criticism of the "Small Judiciary"}

The policy of minimising the judiciary's function through the "Small Judiciary" model has been consistently followed by Japanese governments for one-hundred years. ${ }^{14}$

The Federation of Bar Associations recently argued in favour of the judicial reform, but it is submitted that it did not directly criticise the "Small Judiciary" policy. ${ }^{15}$ The main argument of the Federation of Bar Associations was that the government should improve human and material resources available to the judiciary and increase its budget. The Federation of Bar Associations, when demanding budgetary increases, mainly demanded an increase in the number of judges and refrained from criticising the "Small Judiciary" policy. ${ }^{16}$ The Federation of Bar Associations proposed an increase of the capacity of the judiciary in its "Declaration on Judicial Reform". However, the declaration did not refer to any increase in the number of lawyers. This means that the Federation of Bar Associations was cautious about an increase in the number of successful applicants for the bar examina-

Takashi Suganuma, "Towards a Significant Increase of the Budget for the Judiciary", Legal Reform for Citizens by Centre for promotion of law reform in the Federation of Bar Associations, Vol. 7, November 1996, p. 2.

13 Ibid., p. 3.

14

15

16

Ibid., p. 87.

T. Takahashi, supra, p. 86 .

Keynote Report II (May 1993), in: Judicial Symposium No. 14 (held in November 1992), p. 14 ff. Also see Keynote Report I (May 1991), in: Judicial Symposium No. 13 (held in November 1990), p. $39 \mathrm{ff}$. 
tion. In its "Outline of Fundamental Reform of Bar Examination and Legal Professional Training" (December 1994, the Federation of Bar Associations) an increase of the population of lawyers was advocated. However, it should also be noted that there was a conservative faction which advocated an increase in the capacity of the judiciary without resulting in an increased supply of lawyers.

A pamphlet issued in June 1994 by the Japan Association of Corporate Executives titled "Problems of Japanese Modern Society and Its Remedies" notably influenced public perception of judicial reform. This pamphlet severely criticised the judiciary and in turn triggered criticism by various newspapers since August 1995 on Japanese judicial policy.

Since August 1995, various newspapers started to focus on the "Small Judiciary" policy and the unsatisfactory functioning of the judiciary. The media pointed out that the current state of the judiciary derived from the state's policy to limit closely the tasks entrusted to the judiciary. According to this criticism, judicial reform should not be limited to an increase in the number of the legal profession but should also include an increase in the number of the entire body of lawyers (i.e. include an increase in the number of judges and prosecutors). It should also comprise a reform of laws relating to civil proceedings and legal aid.

An editorial in the Nikkei Newspaper entitled "Expansion of 'Small Judiciary' Prompted by Deregulation" (24 August 1995), Professor Haruo Shimada's article "Japan Should Strengthen Its Judiciary" (ibid., supra) and an editorial by the Mainichi Newspaper "Abolition of Judicial Self-Restraint Urged" (Morning edition 26 November 1995) are examples of this argument. 17

Editorials in newspapers pointing out the necessity of judicial reform and fundamental problems with the judiciary have multiplied since then, pointing to a lack of judges, insufficient legal aid to pay for the cost of litigation for impecunious litigants and a lack of sense of presence of the judiciary in Japanese society, and calling on "the new Chief Justice (of the Supreme Court) to identify the role of the judiciary and its current defects and problems".

In this regard, it was also noted that the government's budget is less than one hundredth of the Anglo-European countries.

An evolution of the attitude of the Federation of Bar Associations has also recently become apparent. For example, "the malfunctioning of the judiciary system derives from the fact that the post-war judiciary system has been intended to remain as the "Small Judiciary" in 
its relationship with politics and the economy" (Osamu Horino, Chairman of the Committee for Judiciary Issues under the Federation of Bar Associations) ${ }^{18}$; or

"we feel the keen necessity for transforming the "Small Judiciary" into a "Bigger and Improved Judiciary ...

If there is any problem with the judiciary, it is imperative to ascertain its origin and necessary remedies. The current judiciary is malfunctioning because the judiciary policy has been neglected. This is evidenced by the fact that the budget for the judiciary has been low for a long period of time. Hence the problems should not be simply attributed to the lack of lawyers.

It is necessary to increase the number of judges and prosecutors as well as lawyers. It is impossible to have an expedition and fair trial where one judge deals with 200 cases so regularly.

The De-regulation Subcommittee of the Administration Reform Committee appears to unfairly underestimate the judiciary reform made by lawyers including the Federation of Bar Associations.

The Judiciary has been ignored for over 50 years after the War. We keenly feel the necessity with reforming the "small Judiciary" to make it a "bigger and efficient judiciary". For this purpose it is very important to effect judicial reform to implement a system which is easily accessible to the public and which can achieve expedient and fair resolutions of disputes.

Thus, the Federation of Bar Associations in its Extraordinary Journal Meeting on 2 November, proposed commencement of judiciary reform and an increase in the number of successful applicants of the bar examination to 1000 per annum from about the year 1999." 19

Subsequently, at its extraordinary general meeting held in November 1995, the Federation of Bar Associations determined to argue in favour of increasing the number of successful applicants of the Bar Examination to 1,000. The current attitude of the Federation of Bar Associations indicates its departure from the "Small Judiciary" policy. ${ }^{20}$

19 Tolıu Motobayashi (Deputy President of the Federation of Bar Associations), in: The Asahi Newspaper, 6 December 1995, p. 4.

20

T. Takahashi, supra, p. 90. 


\section{Problems associated with reform from "Small Judiciary" to "Big Judiciary"}

Prime Minister Hashimoto's administration regards as its priority the creation of an efficient small government and state system by achieving a comprehensive administrative and financial reform. This enjoys much public support. Given this government priority, it is possible to argue that change from a "Small Judiciary" to a "Big Judiciary" would go against current government policy, but such criticism would seem misplaced. The purpose of administrative and financial reform is to reduce duplication and redundancy in the government and make it more efficient, but not to reduce the size of the government uniformly.

We have referred above to the situation where the judiciary is not fulfilling its function due to the neglect of the past one-hundred years. It is not incompatible with administrative and financial reform to normalise the judiciary's function which has in the past been excessively reduced. There are many other issues related to the reform of the judiciary system. In particular, the following should be mentioned ${ }^{21}$ :

An increase in the number of lawyers will lead to a competition amongst lawyers which will in turn lead to service being provided for more appropriate fees. In order to solve the problem of a shortage of judges, appointments to the bench from private practising lawyers will probably increase. Therefore, an increase in the number of lawyers would help to address a shortage of judges. This would not only increase the number of full-time judges but also provide a source of part-time judges for a system of part-time judges which may be introduced in the future.

The Japanese legal aid system as stated above is far from satisfactory. The fundamental infrastructures for legal aid must be radically enlarged. Currently, legal aid is limited to litigation and it is submitted that legal advice other than for litigation should be covered by the legal aid system. ${ }^{22}$ For this purpose it is necessary to introduce a government-funded legal aid system.

The Scale of Legal Fees issued by Japan's Federation of Bar Associations provides for an up-front fee system. This sometimes created an obstacle for the public to have access to the judicial system. Introduction of a contingency fees system will facilitate access to the system for the public.

For detailed aspects of the reform, cf. "Problems and the Remedies of a Modem Judiciary System" by Tokyo Bar Association, Kisei Kai (ed.), October 1995.

22

In this regard see "Fundamental Problems with Legal Aid", The Legal Aid Association (ed.), Daiichi Hohki Publishing Company, 1992, and "An Examination of Some Foreign Legal Aid Schemes" by Peter Huxtable (Japanese version 1997, Legal Aid Association). 
Large cities such as Tokyo or Osaka have only one District court which is the same number as the number of the District Courts in less populated prefectures. In the more populous cities, the government shoud establish more than one District Court to expedite court proceedings.

"Issues related to the number of the courts which related to the number of the judges should also be examined for the purposes of reducing delays in litigation. The notion of increasing the court personnel may work against the idea of small and efficient government. However, reform or restructuring of an organisation does not always mean reducing the size of the organisation, but of ten it means making the organisation more efficient. It is doubtful whether it is appropriate to establish one District Court per prefecture regardless of whether it is the least populated prefecture or a local government which has $10 \%$ of the Japan's entire population such as Tokyo (this argument disregards the number of judges and bench offices in one district). Densely populated prefectures such as Tokyo should have more District Courts. In fact, Hokkaido has more than one District Court. It is possible to divide the Tokyo District Court into several jurisdictions. For example the existing Hachiohji branch may be made an independent jurisdiction and further, the metropolitan area can be divided into as many as four districts (e.g. North, East, West and South Districts).

It defies common sense to install the same number of district courts in the less populated prefectures and densely populated prefectures. It may be possible to adjust the proportion by the number of judges and size of the district court; however, it appears that the current problems go beyond such temporary remedies.

The reform of infrastructure such as courts (which inevitably leads to an increase in the number of judges and an increase in the number of successful applicants of the bar examination) is generally recognised to be necessary. However this requires a budget rearrangement which has not yet been contemplated. This is a very grievous situation in terms of the future judiciary system of Japan." 23

By virtue of the new Civil Procedure Code, final appeal to the Supreme Court has been limited and the vurden of the Supreme Court has been somewhat lessened. However, as the Supreme Court is the final court exercising jurisdiction to determine on unconstitutionality of legislation, the Supreme Court plays a large role in the court system. It is expected that the heavy burden of the Supreme Court cannot be sufficiently addressed by the Civil Procedure Code so long as the Supreme Court only comprises 15 Justices. Therefore, it is submitted that the number of investigators who assist the Supreme Court Justices should be substantially increased. 


\title{
ABSTRACTS
}

\section{The Community of the Portuguese Speaking Countries (1)}

\author{
By Paulo Canelas de Castro
}

On July 17, 1996 the Community of the Portuguese Speaking Countries (Comunidade dos Países de Língua Portugesa - CPLP) was created as an association of seven States, not characterized by a regional coherence, but primarily by a language and a "regionalism of identity". The article surveys the constituent treaty, especially regarding the institutions provided and their functioning. The second focus is on the objectives of the international organization in multilateral diplomacy, internal cooperation and promotion and diffusion of the Portuguese language and its orientating principles. Finally, the author compares the CPLP structures to the British Commonwealth from a political and legal perspective.

The second part of the article on the emerging identity of the CPLP, its status in global international relations and perspectives of an own human rights policy will be published in the coming volume of VERFASSUNG UND RECHT IN ÜBERSEE.

\section{Issues on the "Small Judiciary" Policy in Japan}

\section{By Akira Ishikawa}

Facing serious problems regarding the effectiveness of its judicial system, the Japanese public has been discussing different concepts for a reform from the "Small Judiciary" (Chiissna Shiho) to the "Big Judiciary" (Ohkina Shiho) policy. The present "Small Judiciary" concept is based on a low number of legal professionals and, in the eyes of the author, inadequate human and material resources and an inaccessible court system. This not only causes delays in court jurisdiction and high costs, but at the same time minimizes the role of the judiciary in relation to the administration. The paper compares the figures marking the situation of the legal profession in comparison to other industrialized nations.

The article discusses some of the aspects of the present system and the criticism within the Japanese society, especially from lawyers and executive managers. Reform measures towards a "Big Judiciary" system are suggested - such as creating a new legal aid system, a reform of legal fees and the number of courts - and their effects are discussed. 